\title{
Crucial Role of Insulin in Leptin Maintenance: Profound Decrease in Serum Leptin by Octreotide Acetate in Insulinoma Subjects
}

\author{
Tomoatsu NAKAMURA, Shoichiro NAGASAKA, SAN-E ISHIKAWA, MutSuKo NONAKA, \\ KaZUToshi FUJIBAYASHI, TaKaKo SAITO, IKUyo KUSAKA, Minori HIGASHIYAMA \\ AND TOSHIKAZU SAITO
}

Division of Endocrinology and Metabolism, Department of Medicine, Jichi Medical School, Tochigi 329-0498, Japan

\begin{abstract}
To further clarify the relationship between insulin and leptin, time course changes in plasma glucose, serum insulin and leptin levels were analyzed after subcutaneous administration of $100 \mu \mathrm{g}$ octreotide acetate in two insulinoma subjects. Octreotide acetate induced a prompt decrease in serum insulin level, accompanied with an increase in plasma glucose in both patients. Following the decrease in serum insulin level, serum leptin concentrations were profoundly decreased by $66 \%$ and $44 \%, 8-12 \mathrm{hrs}$ after octreotide injection; that is, the concentrations decreased from 41.1 to $13.8 \mathrm{ng} / \mathrm{ml}$ in patient 1 , and from 17.5 to $9.8 \mathrm{ng} / \mathrm{ml}$ in patient 2. Daily profiles of plasma glucose, serum insulin and leptin without octreotide administration did not show such alterations in these indexes in patient 1. These data show that circulating leptin may be susceptible to decline dependent on the decrease in serum insulin, suggesting that insulin plays a crucial role in the maintenance of leptin secretion in humans.
\end{abstract}

Key words: Leptin, Insulin, GH, Octreotide acetate, Insulinoma

(Endocrine Journal 47: 359-364, 2000)

INSULIN increases leptin mRNA in isolated adipocytes $[1,2]$, and close correlations have been demonstrated between insulin and leptin. In humans, both serum insulin and leptin concentrations rise higher in accordance with an increase in body mass index (BMI) [3]. Although it is still controversial whether the association between insulin and leptin reflects a direct causal relationship or is merely mediated by coexisting hyperinsulinemia and greater fat mass in obesity, recent data seem to favor the former possibility. Hyperinsulinemia closely associates with serum leptin in insulinoma subjects,

Received: January 20, 2000

Accepted: March 24, 2000

Correspondence to: Tomoatsu NAKAMURA, M.D., Division of Endocrinology and Metabolism, Department of Medicine, Jichi Medical School, 3311-1 Yakushiji, Minamikawachi, Tochigi 329-0498, Japan and both hyperinsulinemia and hyperleptinemia ameliorate after the surgical removal of the insulinomas $[4,5]$. Diabetic subjects treated with insulin also had higher leptin concentrations than those treated without insulin [6].

Apart from these observations in chronic phase, leptin mRNA expression in vivo is promptly increased by feeding in rodents [1]. This postprandial increase might be attributed to the direct action of insulin, and is thought to participate in regulating food intake and energy expenditure in rodents [1]. In contrast, leptin mRNA expression can be enhanced in human adipocytes only after incubation with insulin for longer than $72 \mathrm{hrs}[2,7]$, and prolonged and supraphysiological insulinemia is necessary to significantly increase serum leptin in healthy subjects [2] and in type 1 diabetic patients with ketoacidosis or ketosis [8, 9]. These results suggest that leptin secretion is robust against stimu- 
lation by insulin in humans. On the other hand, fasting induces a greater decline in serum leptin than the expected by a decrease in body fat [10]. To clarify the role of insulin in leptin maintenance, we examined the acute effect of a long-acting somatostatin analogue, octreotide acetate, on serum leptin levels in two insulinoma subjects, and found a rapid and drastic decrease in serum leptin, following the decrease in insulin levels.

\section{Subjects and Methods}

\section{Subjects}

Patient 1. A 59-year-old man, with a BMI of $39.4 \mathrm{~kg} / \mathrm{m}^{2}$, was found to have hypoglycemia and concomitant hyperinsulinemia by the survey of unconsciousness. During intravenous glucose infusion, plasma glucose and serum insulin levels were $1.9 \mathrm{mmol} / \mathrm{l}$ and $1220 \mathrm{pmol} / \mathrm{l}$, respectively. Serum leptin concentration was as high as $104 \mathrm{ng} / \mathrm{ml}$. Abdominal echogram and computed tomography demonstrated a $3.0 \mathrm{~cm}$ hypervascular mass in the pancreatic body, which was later confirmed as an insulinoma by surgical procedure. For relief from hypoglycemic symptoms, octreotide acetate $12.5 \mu \mathrm{g}$ was administered twice daily, and octreotide acetate challenge was performed under this condition.

Patient 2. A 60-year-old woman, with a BMI of $28.1 \mathrm{~kg} / \mathrm{m}^{2}$, was referred to our division for the evaluation of hypoglycemia. Her fasting plasma glucose and insulin levels were $2.0 \mathrm{mmol} / 1$ and $122 \mathrm{pmol} / \mathrm{l}$, respectively. The ratio of fasting insulin to glucose (Fajans index) was 0.57 (normal upper limit is 0.30). Abdominal echogram revealed a $1.6 \mathrm{~cm}$ low echoic mass in the pancreatic body. Intra-arterial stimulation with calcium $(0.025 \mathrm{mEq}$ $\mathrm{Ca}^{2+} / \mathrm{kg}$ body weight) into the proximal splenic artery produced a twenty-fold elevation in insulin levels in the right hepatic vein at 30 seconds, while injection of calcium into the gastroduodenal, distal splenic, and hepatic artery failed to demonstrate the insulin gradients [11].

\section{Octreotide acetate challenge}

In both patients, time course changes in plasma glucose, serum insulin, leptin and GH levels were analyzed after a subcutaneous administration of $100 \mu \mathrm{g}$ octreotide acetate (Sandostatin ${ }^{\circledR}$, Sandoz, Switzerland) at $0800 \mathrm{~h}$. Briefly, blood collections were made at intervals of $4 \mathrm{hrs}$ for $20 \mathrm{hrs}$. Breakfast and lunch were allowed at $0800 \mathrm{~h}$ and at $1200 \mathrm{~h}$ after the blood sampling, respectively, and dinner at $1800 \mathrm{~h}$. In patient 1 , the time course changes in plasma glucose, serum insulin and leptin levels were also determined without octreotide acetate. The protocol was approved by the local ethical committee of Jichi Medical School, and informed consent for collection of blood was obtained from the two patients.

\section{Measurements}

Plasma glucose concentrations were measured by the glucose-oxidase method. Serum insulin and GH concentrations were determined by insulin and GH RIA kits, and serum leptin by leptin RIA kits (Linco Research Inc., St. Charles, MO). The intra- and inter-assay coefficients of variation were less than $5 \%$ for leptin.

\section{Statistical analysis}

In patient 1 , the relationship between serum insulin and leptin was assessed by linear regression analysis using the statistical package of StatView for Macintosh, version 4.1. A p-value less than 0.05 was considered significant.

\section{Results}

In patient $1,100 \mu \mathrm{g}$ octreotide acetate induced a prompt decrease in serum insulin, accompanied with an increase in plasma glucose (Fig. 1B). Following the decrease in serum insulin, serum leptin levels were also profoundly decreased from 41.1 to $13.8 \mathrm{ng} / \mathrm{ml}$ (by $66 \%$ ) $12 \mathrm{hrs}$ after the octreotide administration. Serum GH concentration was suppressed from 1.3 to less than $0.2 \mathrm{ng} / \mathrm{ml}$ during octreotide challenge (Fig. 1B). Daily changes in plasma glucose, serum insulin and leptin levels did not show such alterations on the day without octreotide acetate (Fig. 1A). After tumor resection, plasma glucose level increased to $5.2 \mathrm{mmol} / \mathrm{l}$, and serum insulin and leptin concentrations decreased to $36 \mathrm{pmol} / 1$ and $8.6 \mathrm{ng} / \mathrm{ml}$, respec- 


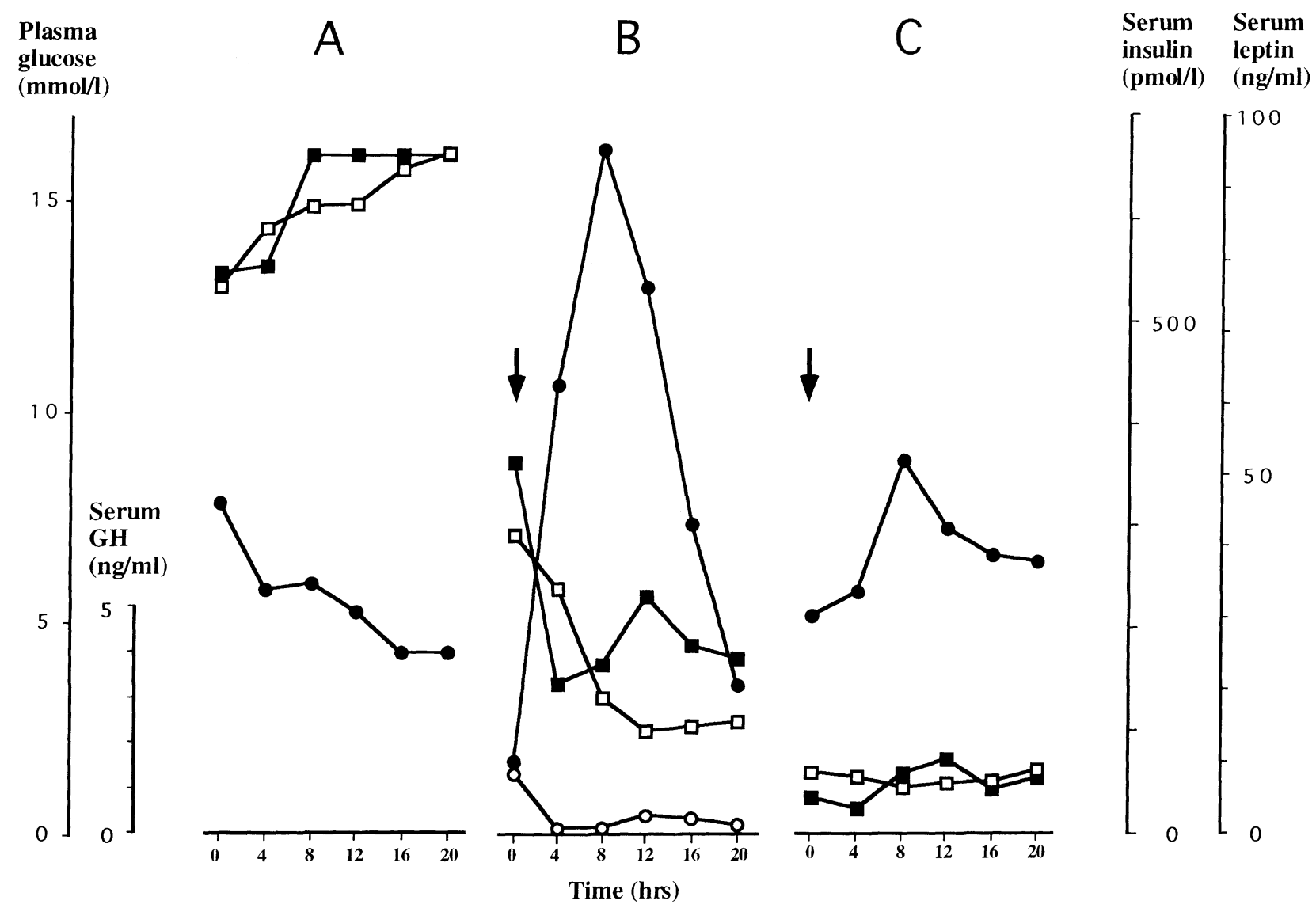

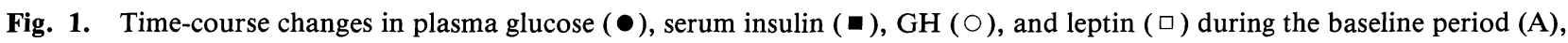
by octreotide acetate treatment before (B) and after tumor resection (C) in patient 1. Arrows show subcutaneous administration of $100 \mu \mathrm{g}$ octreotide acetate. Note that $12.5 \mu \mathrm{g}$ octreotide acetate had been administered twice daily before the octreotide treatment (B).

tively. In this condition, the subcutaneous injection of $100 \mu \mathrm{g}$ octreotide acetate decreased serum insulin level from 36 to $25 \mathrm{pmol} / \mathrm{l}$ (by $31 \%$ ) after $4 \mathrm{hrs}$, followed by decrease in serum leptin concentration from 8.6 to $6.4 \mathrm{ng} / \mathrm{ml} \mathrm{(by} \mathrm{26 \% )} \mathrm{after} 8 \mathrm{hrs}$ (Fig. 1C). During these investigations, serum insulin and leptin levels were simultaneously measured in the 48 samples: 24 samples during the baseline period, 17 by the octreotide challenge, and 7 by the challenge after tumor resection. There was a close positive correlation between serum insulin and leptin levels both in the overall samples $(n=48, r=0.899, P<0.0001)$ and in the samples of octreotide acetate treatment $(n=24$, $\mathrm{r}=0.750, \mathrm{P}<0.0001$ ) (Fig. 2).

In patient $2,100 \mu \mathrm{g}$ octreotide acetate decreased serum insulin level from 97 to $30 \mathrm{pmol} / 1$ and increased plasma glucose from 2.2 to $17.1 \mathrm{mmol} / \mathrm{l}$ after $4 \mathrm{hrs}$. Serum leptin concentration was decreased from 17.5 to $9.8 \mathrm{ng} / \mathrm{ml}$ (by $44 \%$ ) $8 \mathrm{hrs}$ after octreotide administration. Serum GH levels fluctuated between 0.1 and $1.5 \mathrm{ng} / \mathrm{ml}$ (Fig. 3).

\section{Discussion}

After the subcutaneous administration of $100 \mu \mathrm{g}$ octreotide acetate, the serum insulin levels were markedly decreased, accompanied with an increase in plasma glucose in the two insulinoma subjects. Following the decrease in insulin, rapid and profound reduction in serum leptin levels was observed. In contrast, such alterations in plasma glucose, serum insulin and leptin levels were not observed in the daily profiles without octreotide administration in patient 1. Thus, it appears that the acute fall in serum insulin resulted in a decrease in serum leptin levels 


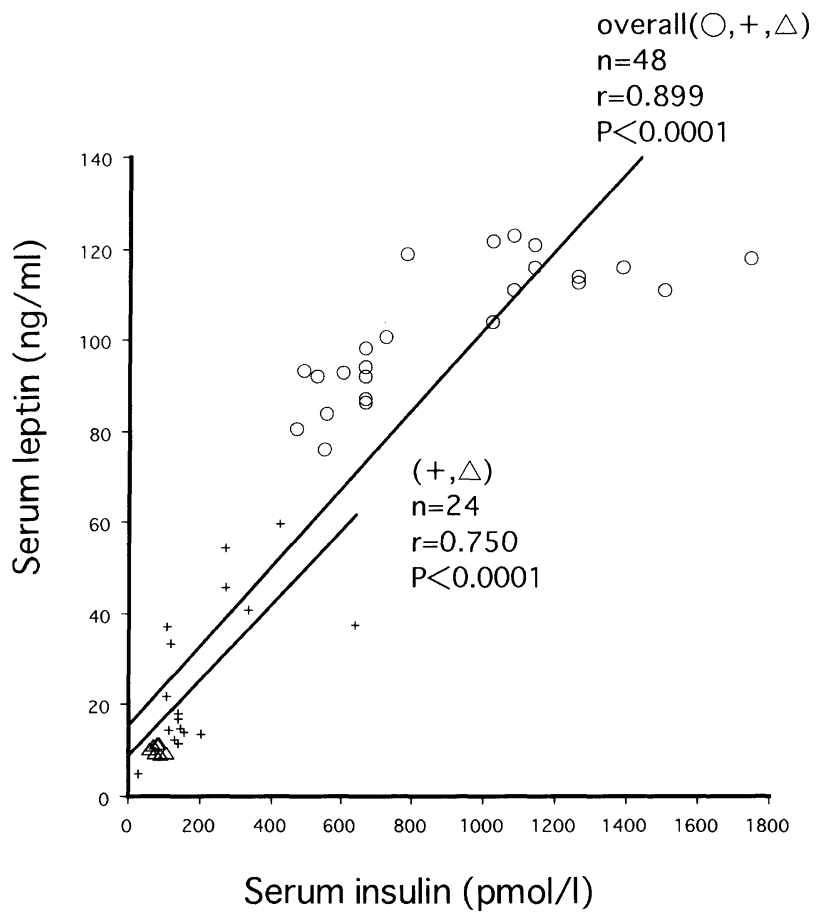

in these two subjects. We observed a close association between serum insulin and leptin levels in patient 1 , which was not disturbed by octreotide administration (Fig. 2). These results also suggest that somatostatin promptly reduces serum leptin levels probably through a decrease in serum insulin.

However, several factors should be considered which could affect the relationship of insulin and leptin in the present study. First, somatostatin suppresses GH secretion from anterior pituitary gland [12], and serum leptin concentrations are elevated in GH-deficient hypopituitary adults [13]. We found slight decreases in serum GH concentrations during octreotide challenge, but the decreases were minor

Fig. 2. Relationship between serum insulin and leptin levels in patient 1 , which were simultaneously measured during the baseline period $(O, n=24)$, by octreotide acetate treatment before $(+, n=17)$ and after tumor resection $(\triangle, n=7)$.
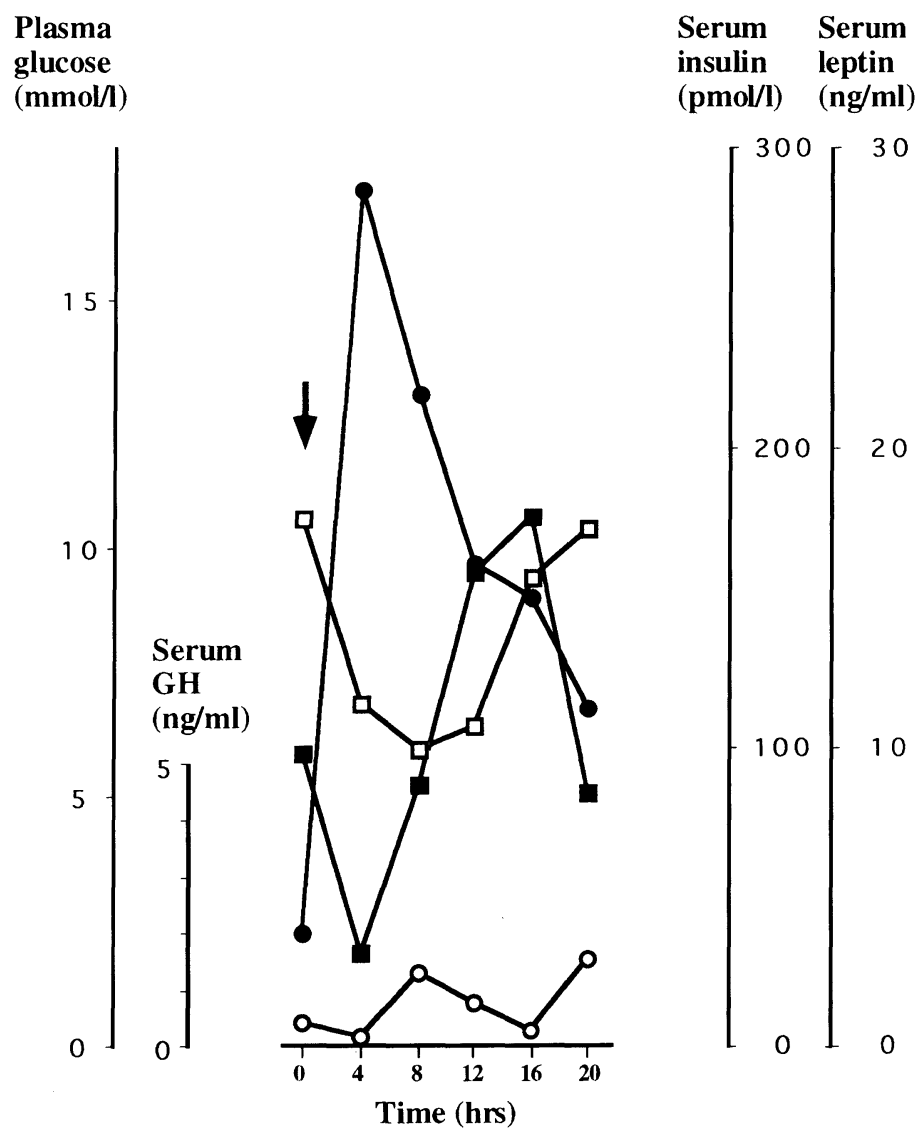

Fig. 3. Time-course changes in plasma glucose ( $\bullet$ ), serum insulin ( $\square)$, GH (O), and leptin ( $\square$ ) by octreotide acetate treatment in patient 2. Arrow shows subcutaneous administration of $100 \mu \mathrm{g}$ octreotide acetate. 
and inconsistent with the marked decrease in serum leptin. Secondly, Donahoo et al. [14] suggest that somatostatin may have a direct suppressive effect on serum leptin concentrations. Due to the observational nature of the present study, such a direct effect of somatostatin cannot be fully excluded. Further study is needed to clarify the direct effect of somatostatin on leptin production in adipocytes.

In Figure 2, the correlation between serum insulin and leptin levels seems solid up to a serum insulin concentration of $1000 \mathrm{pmol} / \mathrm{l}$, but a further increase in serum insulin no longer raised serum leptin level. In this subject, extreme hyperinsulinemia was frequently associated with severe hypoglycemia. Hypoglycemia per se may limit further increase in serum leptin concentration, since an influx of glucose is an important signal which regulates leptin secretion from adipocytes [15]. As some studies showed that glucose uptake by fat and muscle was not changed in vitro [16], or even increased in fasting dogs [17], by somatostatin administration, it is unlikely that somatostatin can affect an influx of glucose, thereby reducing circulating leptin levels.

It is well known that fasting induces a decline in serum leptin. We have also confirmed that serum leptin concentrations gradually decreased to about $33-47 \%$ of the initial values during $48 \mathrm{hr}$ fasting in obese and normal-weight volunteers [9]. Simultaneously, serum insulin levels were decreased to about $32-51 \%$ of the initial values [9]. Saad et al. [18] revealed that a very low dose insulin infusion could abolish such a decline in serum leptin during $9 \mathrm{hr}$ fasting. The present results, together with these data, indicate that circulating leptin is susceptible to decline, presumably dependent on the decrease in serum insulin. In contrast, the prevailing observations from human studies suggest that leptin secretion is rather robust against the acute stimulation by insulin, as mentioned in the introduction [2, 7-9]. These characteristics of the relationship between insulin and leptin in humans seem favorable to gain and maintain body fat, together with the well-described "leptin resistance" in obesity. An insulin-leptin system may be constructed as a part of "thrifty genes" in humans.

\section{References}

1. Saladin R, De VP, Guerre MM, Leturque A, Girard J, Staels B, Auwerx J (1995) Transient increase in obese gene expression after food intake or insulin administration. Nature 377: 527-529.

2. Kolaczynski JW, Nyce MR, Considine RV, Boden G, Nolan JJ, Henry R, Mudaliar SR, Olefsky J, Caro JF (1996) Acute and chronic effects of insulin on leptin production in humans: Studies in vivo and in vitro. Diabetes 45: 699-701.

3. Considine RV, Sinha MK, Heiman ML, Kriauciunas A, Stephens TW, Nyce MR, Ohannesian JP, Marco CC, McKee LJ, Bauer TL (1996) Serum immunoreactive-leptin concentrations in normal-weight and obese humans. New Engl J Med 334: 292-295.

4. D'Adamo M, Buongiorno A, Maroccia E, Leonetti F, Barbetti F, Giaccari A, Zorretta D, Tamburrano G, Sbraccia P (1998) Increased OB gene expression leads to elevated plasma leptin concentrations in patients with chronic primary hyperinsulinemia. Diabetes 47 : 1625-1629.

5. Popovic V, Micic D, Danjanovic S, Zoric S, Djurovic M, Obradovic S, Petakov M, Dieguez C, Casanueva FF (1998) Serum leptin and insulin concentrations in patients with insulinoma before and after surgery. Eur J Endocrinol 138: 86-88.

6. Nagasaka S, Ishikawa $S$, Nakamura T, Kawakami A,
Rokkaku K, Hayashi H, Kusaka I, Higashiyama M, Saito $T$ (1998) Association of endogenous insulin secretion and mode of therapy with body fat and serum leptin levels in diabetic subjects. Metabolism 47: 1391-1396.

7. Boden G, Chen X, Kolaczynski JW, Polansky M (1997) Effects of prolonged hyperinsulinemia on serum leptin in normal human subjects. $J$ Clin Invest 100: 1107-1113.

8. Flück CE, Kuhlmann BV, Mullis PE (1999) Insulin increases serum leptin concentrations in children and adolescents with newly diagnosed type I diabetes mellitus with and without ketoacidosis. Diabetologia 42: 1067-1070.

9. Nakamura T, Nagasaka S, Ishikawa S, Fujibayashi K, Kawakami A, Rokkaku K, Hayashi H, Saito T, Kusaka I, Higashiyama M, Saito T (1999) Serum levels of leptin and changes during the course of recovery from diabetic ketoacidosis. Diabetes Res Clin Pract 46: 57-63.

10. Boden G, Chen X, Mozzoli M, Ryan I (1996) Effect of fasting on serum leptin in normal human subjects. $J$ Clin Endocrinol Metab 81: 3419-3423.

11. Doppman JL, Miller DL, Chang R, Shawker TH, Gorden P, Norton JA (1991) Insulinomas: localization with selective intraarterial injection of calcium. 
Radiology 178: 237-241.

12. Leblanc H, Rigg LA, Yen SS (1975) The response of pancreatic and pituitary hormones to pulses and constant infusion of somatostatin. $J$ Clin Endocrinol Metab 41: 1105-1109.

13. Al-Shoumer KA, Anyaoku V, Richmond W, Johnston DG (1997) Elevated leptin concentrations in growth hormone-deficient hypopituitary adults. Clin Endocrinol 47: 153-159.

14. Donahoo WT, Jensen DR, Yost TJ, Eckel RH (1997) Isoproterenol and somatostatin decrease plasma leptin in humans: a novel mechanism regulating leptin secretion. J Clin Endocrinol Metab 82: 4139-4143.

15. Mueller WM, Gregoire FM, Stanhope KL, Mobbs CV, Mizuno TM, Warden CH, Stern JS, Havel PJ
(1998) Evidence that glucose metabolism regulates leptin secretion from cultured rat adipocytes. Endocrinology 139: 551-558.

16. Cherrington AD, Caldwell MD, Dietz MR, Exton JH, Crofford OB (1977) The effect of somatostatin on glucose uptake and production by rat tissues in vitro. Diabetes 26: 740-748.

17. Hendrick GK, Frizzell RT, Cherrington AD (1987) Effect of somatostatin on nonesterified fatty acid levels modifies glucose homeostasis during fasting. Am J Physiol 253: E443-452.

18. Saad MF, Khan A, Sharma A, Michael R, Riad GMG, Boyadjian R, Jinagouda SD, Steil GM, Kamdar V (1998) Physiological insulinemia acutely modulates plasma leptin. Diabetes 47: 544-549. 